\title{
Comment on 'Repurposing Hydrocarbon Wells for Geothermal Use in the UK: The Onshore Fields with the Greatest Potential. Watson et al. (2020)'
}

\author{
Alison A. Monaghan ${ }^{1, *}$, David A. C. Manning ${ }^{2}$ and Zoe K. Shipton ${ }^{3}$ \\ 1 British Geological Survey, Lyell Centre, Research Avenue South, Edinburgh EH14 4AP, UK \\ 2 School of Natural \& Environmental Sciences, Drummond Building, Newcastle University, \\ Newcastle upon Tyne NE1 7RU, UK; David.Manning@newcastle.ac.uk \\ 3 Civil and Environmental Engineering, James Weir Building, University of Strathclyde, 75 Montrose Street, \\ Glasgow G1 1XJ, UK; zoe.shipton@strath.ac.uk \\ * Correspondence: als@bgs.ac.uk
}

Received: 14 August 2020; Accepted: 1 December 2020; Published: 2 December 2020

check for updates

Comment: We wish to comment on factual inaccuracies around the purpose of the UK Geoenergy Observatory in Glasgow (GGERFS) in the recent Energies paper by Watson et al. (2020) [1], and the use of an estimated figure from their own work for the resource size, prior to any borehole testing.

In Section 5.2 of [1], comparison on resource size includes the Glasgow Geothermal Energy Research Field Site, part of the UK Geoenergy Observatories. This is misleading as (i) the resource size quoted is an estimate by the same authors [2] who note themselves that 'detailed calculations depend on the hydrology, which has not yet been determined', and (ii) the Glasgow Observatory is a research infrastructure as opposed to being designed for the purpose of maximum heat abstraction.

In [1], the authors then go on to further criticise the scale, depth and cost of the Glasgow Observatory. However, the observatory is not a demonstrator for the maximum abstraction and supply of heat; as a research infrastructure with much wider capabilities, it aims to enable the evidence base, processes and innovation around low-temperature mine water energy resources and environmental management in a representative urban area close to heat users [3-5]. The cost of the observatory includes boreholes and fenced compounds for research incorporating numerous sensors, a wide range of open data including environmental baseline boreholes and monitoring equipment, a contribution to IT infrastructure for open data, etc., that would not be part of a commercial heat production facility. These aspects of [1] are likely to cause misunderstandings for future UK Geoenergy Observatory users, as they do not accurately represent the context of the facility and the way in which it will be used for research.

Author Contributions: Writing-original draft preparation, A.A.M.; writing-review and editing, D.A.C.M. and Z.K.S. All authors have read and agreed to the published version of the manuscript.

Funding: A.A.M. is employed by the British Geological Survey as Science Lead for the Glasgow Observatory. D.A.C.M. is Natural Environment Research Council (NERC) Senior Science User for the UK Geoenergy Observatories. Z.K.S. is voluntary Chair of the UK Geoenergy Observatories Science Advisory Group.

Conflicts of Interest: The authors declare no conflict of interest.

\section{References}

1. Watson, S.M.; Falcone, G.; Westaway, R. Repurposing Hydrocarbon Wells for Geothermal Use in the UK: The Onshore Fields with the Greatest Potential. Energies 2020, 13, 3541. [CrossRef]

2. Watson, S.M.; Westaway, R. Borehole temperature log from the Glasgow Geothermal Energy Research Field Site: A record of past changes to ground surface temperature caused by urban development. Scott. J. Geol. 2020. [CrossRef] 
3. Adams, C.; Monaghan, A.; Gluyas, J. Mining for heat. Geoscientist 2019, 29, 10-15. [CrossRef]

4. Monaghan, A.A.; Ó Dochartaigh, B.E.; Fordyce, F.M.; Loveless, S.; Entwisle, D.; Quinn, M.; Smith, K.; Ellen, R.; Arkley, S.; Kearsey, T.; et al. UKGEOS: Glasgow Geothermal Energy Research Field Site (GGERFS): Initial summary of the geological platform. Br. Geol. Surv. Open Rep. 2017. OR/17/006. Available online: http://nora.nerc.ac.uk/id/eprint/518636/ (accessed on 1 August 2020).

5. Monaghan, A.A.; Starcher, V.; Ó Dochartaigh, B.E.; Shorter, K.M.; Burkin, J. UK Geoenergy Observatories: Glasgow Geothermal Energy Research Field Site: Science Infrastructure Version 2. Br. Geol. Surv. Open Rep. 2019. OR/19/032. Available online: http://nora.nerc.ac.uk/id/eprint/522814/ (accessed on 1 August 2020).

Publisher's Note: MDPI stays neutral with regard to jurisdictional claims in published maps and institutional affiliations.

(C) 2020 by the authors. Licensee MDPI, Basel, Switzerland. This article is an open access article distributed under the terms and conditions of the Creative Commons Attribution (CC BY) license (http://creativecommons.org/licenses/by/4.0/). 